\title{
A EXPERIÊNCIA DA QUEDA: \\ A Noção de Vertigem no Instante Fotográfico
}

\author{
André Figueiredo da Costa \\ Escola de Música e Belas Artes do Paraná
}

\section{RESUMO}

Desenvolvido com base em uma abordagem filosófica e estética, este artigo analisa, em um primeiro momento, o conto Descida ao Maelström, de Edgar Allan Poe, trabalhando, com o conceito de instante fotográfico, a ideia de vertigem a partir da imagem literária. Posteriormente, o conceito é exploradopor meiodo objeto pictórico, A incredulidade de São Tomé, de Caravaggio, no qual o instante fotográfico aparece no confronto fulgurante entre o tangível e o visível,encenando, dessa maneira, o silêncio do mundo. Por fim, analisa-seo vídeo Sal e Prata de Rodrigo Braga no qual o instante fotográfico surge de forma intermitente, refletindo a dicotomia de um Eu que não cessa de buscar sua contra parte perdida no âmbito profuso das imagens digitais, confundindo-se, consequentemente, com aquilo que the é extrínseco. Palavras Chave

Instante, imagem, fotografia, vertigem.

\section{ABSTRACT}

Developed over a philosophical and a esthetic approach, this article analyzes, at first, the tale $A$ Descent in to the Maelström, by Edgar Allan Poe, working through the photographic instant concept the Idea of vertigo from the literary image. Subsequently, such concept is explored by the pictoric object The Incredulity of Saint Thomas by Caravaggioin which the photographic instante merges from the blazing confrontation between the tangible and the visible, staging there of the silence of the world. Finally, the vídeo Sal e Prata by Rodrigo Braga is analyzed, where the photographic instant arises in na intermittent way reflecting the dicho to my of ones elf that do not cease to seek his lost count er partin the profuse Field of digital images, mistaking himself, consequently, by what is extrinsic to him. 
Key words

Instant, image, photography, vertigo.

\section{Introdução}

Nosso objeto de estudo é a imagem. No entanto, um tipo muito específico de imagem. Podemos dizer que nos interessam aquelas imagens que têm o efeito de suscitar-nos uma vertigem. Dessa maneira, acreditamos estar sob o signo do instável, do incorporal, ou do imaterial. Genericamente, chamá-las-emos de imagens da queda. A experiência da queda, a qual terá como mediadora imagens desse tipo, será tratada, aqui, a partir da problemática da imagem fotográfica vista como tentativa de entendimento de uma dada realidade. Isto posto, é por meio da fotografia artística e do conceito de instante fotográfico que queremos ampliar e questionar nosso entendimento da realidade.

A imagem da queda é uma das mais profundamente incrustadas na cultura ocidental, tendo uma remotaorigem teológica, mas também correspondendo ao desejo milenar de escapar às forças gravitacionais que fazem cair todos os corpos para a Terra. (BRAGANÇA DE MIRANDA A.; JOSÉ, 2006, orelha).

$\mathrm{Na}$ contemporaneidade, as imagens da queda, as quais já vinham sofrendo profundas alterações desde a modernidade, reverberam de forma sibilante em campos como a filosofia e a arte. Por conseguinte, temos como objetivo o estudo daprodução e,notadamente,da recepção de tais imagens, ou mais precisamente, o instante em que elas se formam no espectador.

Embasados no conceito de instante fotográfico, primeiramente, deparar-nosemos com a imagem do vórtice sugerida por Edgar Allan Poe em seu conto Descida ao Maelström. Imagem esta que será nossa condutora, possibilitando-nos adentrar em universos subsequentes. Inicialmente, analisaremos o instante fotográfico a partir da imagem literária. Veremos que o instante fotográfico aparecerá como o instante primeiro de uma descida, onde espaço e tempo entram em colapso e dele extrairemos um saber que chamaremos de trágico. Em um segundo momento, com A incredulidade de São Tomé de Caravaggio, analisaremos o instante fotográfico a 
partir da pintura. Aqui, o instante fotográfico aparecerá como o instante último de uma agonia, onde o visível e o tangível é que se irão intercambiar. E, a partir disso, entenderemos de que maneira subjaz sua tragicidade. Um terceiro instante surge na interpretação de Sal e Prata de Rodrigo Braga. Instante este que aparece como intermitente. Tentaremos compreender como, a partir da imagem-movimento (vídeo), o instante, fração de tempo congelada, chega a nós na forma de um 'movimento' que não cessa de existir. E, igualmente aos tópicos precedentes, tentaremos extrair desse instante um saber trágico.

Refletir sobre imagens que suscitam em nós uma experiência vertiginosa leva-nos a pensar em uma sensibilidade contemporânea: a das experiências extremas; e que, para nós, caracterizam os dias de hoje. Partimos do pressuposto de que a experiência relevante da queda é aquela de quando se cai no abismo. O sentido do abismo é sugerido a nós por Poe como sendo a queda em um tempo infinito, experiência limite onde o corpo e o pensamento dissociam-se. Acreditamos que a arte dos dias atuais ocupa o lugar das fronteiras incertas e ambíguas. Este texto adota uma visão estética e filosófica da arte, com o intuito de construir um espaço discursivo. Espaço este que é interdisciplinar e fronteiriço e que tem por objetivo último erigir um pensamento, tanto quanto sugerir uma imagem da contemporaneidade.Aqui, faremos intercursos entre os seguintes campos: literatura, filosofia e arte.

\section{O VÓRTICE}

A queda e seu devir: a vertigem. "Podemos pensar a vertigem como perturbação da mente, repentina e em geral passageira, na qual se nos afigura que todos os objetos giram em redor de nós, ou que nós mesmos giramos" (MICHAELIS,1993, p. 2195). Deduzimos, então, que espaço e indivíduo encontramse em desalinho. Poderíamos pensar a imagem da queda referindo-se ao imaginário? Diz Bachelard sobre a experiência imaginária da queda.

São esses esforços para tornar a subir, esses esforços para tomar consciência da vertigem, que conferem uma espécie de ondulação à queda, que fazem da queda imaginária um exemplo dessa psicologia ondulatória em que as contradições do real e do imaginário se permutam indefinidamente, se reforçam e se induzem por um jogo contrário. Então a 
vertigem se acentua nessa dialética trêmula da vida e da morte, atinge essa queda infinita, experiência dinâmica inesquecível [...] (BACHELARD; GASTON, 2001, p. 97).

Para nós, a imagem artística existe na intersecção entre o sujeito que olha e o objeto que é visto. Dessa maneira, o nosso objeto de estudo não é um objeto estático. É um acontecimento. É, portanto, algo efêmero o nosso objeto, porque manifesta-se como instantee não como matéria. É um flagrante no espaço-tempo; restando-nos a opção de estudá-lo a partir do espaço que o contém. Contudo, queremos situá-lo numa experiência particular, que é a do cair.

Estudando a Queda imaginária na obra de Poe, Bachelard diz que as imagens da queda só podem ser descortinadas se as pegarmos no momento mesmo em que elas acontecem. Em pleno ar. Em geral, são imagens fugazes, trêmulas e ambíguas. São raras. Contudo, "todas elas desenvolvem uma impressão psíquica que, em nosso inconsciente, deixa traços indeléveis: o medo de cair é um medo primitivo"(BACHELARD;GASTON, 2001, p. 91). Nessas imagens, o medo do escuro, da queda no escuro, suscita em nós, ao menos quando sonhamos, quedas em abismos vertiginosos.

Nosso método de trabalho deverá ser à maneira do fotógrafo. Daquele que se interessa pelo instante fulminante e decisivo dos acontecimentos. Estamos, aqui, fazendo referência ao método do fotógrafo Henri Cartier-Bresson. Método que tem por finalidade "captar um acontecimento característico de uma coisa, de um ser ou de uma situação" (SOULAGES;FRANÇOIS, 2010, p. 34).

O acontecimento que queremos fotografar, nós o encontramos no conto Descida ao Maelström (1841) de E. A. Poe, e é ele vorticoso. Por possuir elevada disposição concêntrica, tende a provocar vertigem naquele que se precipita em direção ao seu interior. Queremos capturá-lo no instante mesmo em que ele surge na mente daquele que o imagina. Pois é na miudeza desse fragmento que o vórtice adquirirá sua forma mais plena, e, consequentemente, mais dinâmica e efetiva para nós espectadores. "Para imaginar a vertigem, cumpre reintegrá-la à filosofia do instante, surpreendê-la em sua diferencial total, quando todo o nosso ser desfalece. É um devir fulminante" (BACHELARD; GASTON, 2001, p. 93). 
Encontramos um núcleo de discussão da experiência do cair no conto em questão. Segundo Poe, suas histórias deveriam cumprir o objetivo de causar um efeito específico e único no leitor-espectador. O efeito único e específico que sentimos ao ler a obra em questão é o de estar numa expectativa constante em relação a um fenômeno ou a um objeto que nos está sendo ocultado. Vejamos, resumidamente, do que se trata a história de Descida ao Maelström: um pescador conta ao narrador um acontecimento inaudito, a sua queda num enorme turbilhão onde morreram seus dois irmãos. E extrai algumas lições sobre como conseguiu escapar.

Poe sabe que a imagem relevante do vórtice é aquela que pode causar vertigem no espectador e só existe na medida em que o espectador aceita participar de um jogo. Resta a ele, mero condutor, apresentar ou direcionar o espectador a essa imagem, a qual é particular a cada um de nós. Porque acontece dentro de nós. Só para nós. Imagem que não pode ser compartilhada. Como quando queremos compartilhar com alguém o terror ou a alegria que sentimos em um sonho e somos frustrados pela impossibilidade do outro sintonizar-se com o nosso pavor ou a nossa alegria.

Nosso ponto inicial para encontrar a imagem do vórtice é o método de construção usado por Poe em seu conto. O discurso do terror, como observa Bachelard, "é primeiro comover depois mostrar" (BACHELARD; GASTON, 2001, p. 96). Ou, como veremos em seguida, antes ocultar um espaço e depois concebê-lo. Poe tenta, a partir da perspectiva de seus personagens, construir uma imagem trágica, a qual, nesse conto, é a de um 'grande turbilhão' (vórtice) que ameaça a tudo destruir. No entanto, sempre apaga a imagem que constrói substituindo-a por outra. Somos sempre frustrados na finalização dessa imagem porque a imagem seguinte se sobrepõem à primeira. À imagem do turbilhão segue-se uma série de outras imagens. Todas elas, apesar de dinâmicas e ambíguas, são insatisfatórias; porque não dão conta de revelar a 'realidade' do turbilhão. A imagem do 'grande turbilhão' (Maelström) é constantemente 'atualizada'.

Vejamos uma fotografia ou fragmento do turbilhão encontrada por nós no conto; mas que nos foi sugerida pelo olhar de um dos narradores da história. Eis o fragmento: 
Subitamente, muito subitamente, este assumiu existência distinta e definida, num círculo de mais de uma milha de diâmetro. O bordo do turbilhão era representado por uma larga cintura de espuma luminosa; mas nem uma parcela desta escorregava para a boca do terrível funil cujo inferior, até onde a vista poderia sondá-lo, era constituído por uma parede de água lisa, brilhante e negra de azeviche, inclinada sobre o horizonte segundo um ângulo de cerca de quarenta e cinco graus, girando vertiginosamente sobre si mesma com um movimento arrebatador e estonteante [...] (POE A.; EDGAR, 2006, p. 59).

Contudo, essa nos parece uma imagem distanciada do turbilhão. Esse está sendo descrito, além de estar isolado de seu contexto original, o conto. Isso é fotografia tola, fragmento descartável, porque não podemos sentir seu efeito estonteante e arrebatador. A imagem objetiva (representativa) do vórtice, não pode nos induzir à vertigem, pois a imobilidade e a rigidez de sua aparência (descritiva), não deixam entre-a-ver a amplitude de sua subjetividade. Assim, como esse fragmento que extraímos da obra é arbitrariedade maliciosa, e, pode deformar nosso objeto de estudo subjetivando-o de forma a torná-lo totalmente impreciso. Mas lembremo-nos! Este é mesmo o nosso campo de ação: o da fronteira, o dos limites, mesmo que entre precisão e imprecisão. Então, é preciso lembrar "que para imaginar verdadeiramente, é preciso sempre agir, sempre atacar" (BACHELARD; GASTON, 2001, p. 94). Atacamos essa imagem com outra, do 'criador' mesmo da primeira imagem: o narrador do conto. Eis o segundo fragmento:

As descrições vulgares deste vórtice [...] não nos dá a mais apagada ideia, nem da magnificência, nem do horrível do espetáculo, nem da estranha e perturbadora sensação de novidade, que confunde o espectador (POE A.; EDGAR, 2006, p. 60).

Porém, se atentarmos para uma particularidade escondida nesses dois fragmentos, veremos um 'defeito', um 'borrão', que os torna sutilmente incompletos. O primeiro fragmento começa com Subitamente, muito subitamente... É o modo como a imagem do turbilhão é apresentada ao narrador. A imagem objetiva do turbilhão, a qual se inicia com $O$ bordo do turbilhão, é precedida de outra imagem; obscura, porém imediata. Por um intervalo de tempo muito pequeno não sabemos onde estamos, se aquém ou além da imagem que está a se formar. No segundo fragmento, o qual parece menos uma imagem que uma interpretação sobre a 
imagem precedente, a zona de indefinição ou 'borrão', como foi sugerido acima, encontra-se no centro da imagem. Um jogo de ocultamento aparece na polarização dos sentidos de magnificência e horrível do espetáculo, e nos sentidos também polarizados de estranha e perturbadora sensação. A imagem vacila entre um sentido positivo e outro negativo, tornando-se parcialmente incompleta ou indefinida.

Nas primeiras linhas do conto, a imagem que se apresenta primeiramente ao espectador-leitor é: "Atingíramos o cume do rochedo mais alto. Durante alguns minutos o velho pareceu não poder falar, de cansado" (POE A.; EDGAR, 2006, p. 55).Antes mesmo que consigamos perceber o espaço próprio dessa imagem, seu cenário, sua paisagem, já estamos inseridos dentro dele, e, não só estamos no cume de um rochedo, como também estamos no rochedo mais alto dentre todos os outros. Como é possível? Tudo tão rápido! A imagem que se consolida em nossa mente após visualizarmos a segunda parte do fragmento, apesar de nos fornecer mais informação sobre o espaço em que estamos inseridos, não anula a sensação de incompletude sugerida inicialmente por ela. Ao que nos parece, Poe inicia a construção de um espaço precedido de outro, o qual nos é ocultado. Algo aconteceu, bem o sabemos (Atingíramos), mas, onde estávamos? Não lembramos. Então, deixamos para trás e prosseguimos confiante?

Olhemos mais de perto o turbilhão. Avancemos na história, em direção ao seu centro. As descrições do Maelström, que agora são narradas pelo segundo narrador (o pescador), deixam de ser distanciadas como fotos aéreas de um campo minado para se tornarem abstrações (ou close-up) de um cenário aterrorizante no qual nos apercebemos imersos. Aproximamo-nos lentamente da margem do grande Maelström.

Em menos de um momento, a tempestade estava sobre nós - um minuto depois, o céu toldava-se inteiramente - e com isto e com a espuma que havia no ar, a escuridão tornou-se de súbito tão cerrada que mal nos podíamos ver uns aos outros no barco (POE A.; EDGAR, 2006, p. 67).

Paisagem oculta, pois estamos de olhos cerrados. Porém, de ouvidos dilatados. O terror em Poe, como indica Bachelard (2001, p.101), "não vem do objeto, dos espetáculos sugeridos pelo contista; o terror é incessantemente animado e reanimado no sujeito [...] ". O elemento trágico de Descida ao Maelström está no 
ocultamento de uma ação. Ou então, na maneira do artista pensar e articular o espaço e o tempo. O espaço, ora é dado, ora sugerido. Dessa maneira, o tempo é estendido. É dilatado. É um instante que dura infinitamente. E, por isso, parece estar imóvel. É fotográfico. É mortal. É nostálgico?

A ação em Poe que, aqui para nós, apresenta-se como imagem, desenvolvese até um ponto limite onde o leitor-espectador é conduzido a experimentar, junto ao protagonista, o desafio de sobreviver a um vórtice que se abre no meio do mar e ameaça a tudo tragar. O cenário descrito por Poe não é só de desintegração da matéria: do barco, dos objetos que o compõem, do corpo físico dos personagens que lutam para se manterem vivos. Aquilo que se desintegra é uma perspectiva particular do ser. O protagonista, antevendo a certeza do seu fim, do seu encontro com a morte, não reluta. Não há o que fazer. E, é nessa aparente não-ação que o protagonista escapa da morte. O que acontece nesse encontro entre o pescador e a morte é uma mudança de perspectiva do personagem. Suas convicções e sua vontade são colocadas em suspensão para adequar-se a uma realidade outra, na qual vigora outra lógica, outra percepção, outra sensibilidade. Uma sensibilidade mais condizente com a velocidade e transitoriedade de sua situação atual. Uma sensibilidade vertiginosa. O que salva nosso narrador é sua escolha improvável: a diversão. Um estranho relaxamento que Ihe possibilita refletir diante de uma situação limite.

De que maneira se pode cair? Como caem os personagens aqui? Existem três formas de cair e cada uma é expressa em três situações diferentes. A primeira queda é a do irmão mais novo. Aqui, a racionalidade, o apego e confiança na tecnologia, simbolizado pelo mastro, é que estão sendo colocados à prova.

Mas, à primeira rajada, ambos os nossos mastros foram pela borda afora, como se tivessem sido serrados pela base - e o mastro grande levou consigo meu irmão mais novo, que se tinha agarrado a ele para se segurar (POE A.; EDGAR, 2006, p. 67).

A segunda queda é expressa pela situação do irmão mais velho. Aqui, é o instinto que domina. Tem-se a queda moral. Revela-nos o pescador-narrador:

Quando nos aproximávamos da beira do abismo, ele deixou o barril e segurou-se à argola, da qual, na agonia do seu terror, tentou arrancar-me 
as mãos, por não ser tão grande que nos oferecesse aos dois espaço suficiente para nos agarrarmos. Nunca senti mágoa tão profunda como quando o vi tentar fazer aquilo - embora soubesse que estava fora de si, completamente enlouquecido pelo medo (POE A.; Edgar, 2006, p. 72-73).

A terceira queda é alternativa. É a via do conhecimento trágico a qual o pescadornarrador escolhe. Aqui, não é o apego à técnica ou o impulso primitivo de sobrevivência que é privilegiado. Diz o pescador-narrador:

Tive já ocasião de falar na estranha curiosidade que se substituíra aos meus primitivos terrores. Parecia aumentar em mim, à medida que me aproximava do meu horrível destino. Comecei então a observar com estranho interesse as numerosas coisas que flutuavam na nossa companhia. Devia estar delirante, porque até procurei divertir-me calculando as velocidades relativas das descidas para o turbilhão de espuma (POE A.; Edgar, 2006, p. 75)

O método de Poe tem por finalidade deixar-nos em um estado de expectativa constante (suspensão), a partir da discrepância entre espaço e tempo. Entre aquilo que está findo e aquilo que está por vir. Seu método é a repetição de imagens incompletas. Dessa maneira, circunscreve seu real objeto. O objeto do qual nos fala Poe não pode ser representado pois, não há representação possível para ele. Resta ao artista sugeri-lo. "O vórtice é deduzido da queda. A imagem é deduzida do movimento" (BACHELARD; Gaston, 2001, p. 95). Percebemos com isso, que o nosso método de querer capturar a imagem do vórtice de Poe, à maneira de CartierBresson, mostrou-se ineficaz. Acreditando poder fotografar a essência do vórtice, capturamos apenas a imagem de um fenômeno temporal e temporário. Atingir a essência do vórtice é fotograficamente impossível. O vórtice em Poe é uma máquina não-humana que gira em alta velocidade, diluindo coisas, espaço, tempo e pensamento, e, consequentemente, a ideia de fotografia que aqui esboçamos. Ao final do conto, temos a sensação que nada é fixo e sentimos que "a cortina, amplo pano mortuário, desce com a violência da borrasca" (POE; A. Edgar, in BACHELARD; Gaston, 2001, p.103).

Dois saberes: um niilista, outro trágico. Dois espaços: um real, outro imaginário. Dois tempos: um contínuo, outro descontínuo. Poe busca o saber trágico para lidar com a catástrofe iminente. Um conhecimento da dor. Um conhecimento do vórtice. Um conhecimento para dar conta de um espaço-tempo em desalinho, em 
que as regras e verdades do passado e do presente não mais se sustentam. Mas que saber é este? "Um saber feito de intensidades, marcado pela estranheza" (BRAGANÇA De Miranda A.; JOSÉ, 2006, p. 43). E do que nos serve isso? Bragança de Miranda diz que é o único saber capaz de lidar com o niilismo, o qual em nossos dias parece ter assumido sua forma plena.

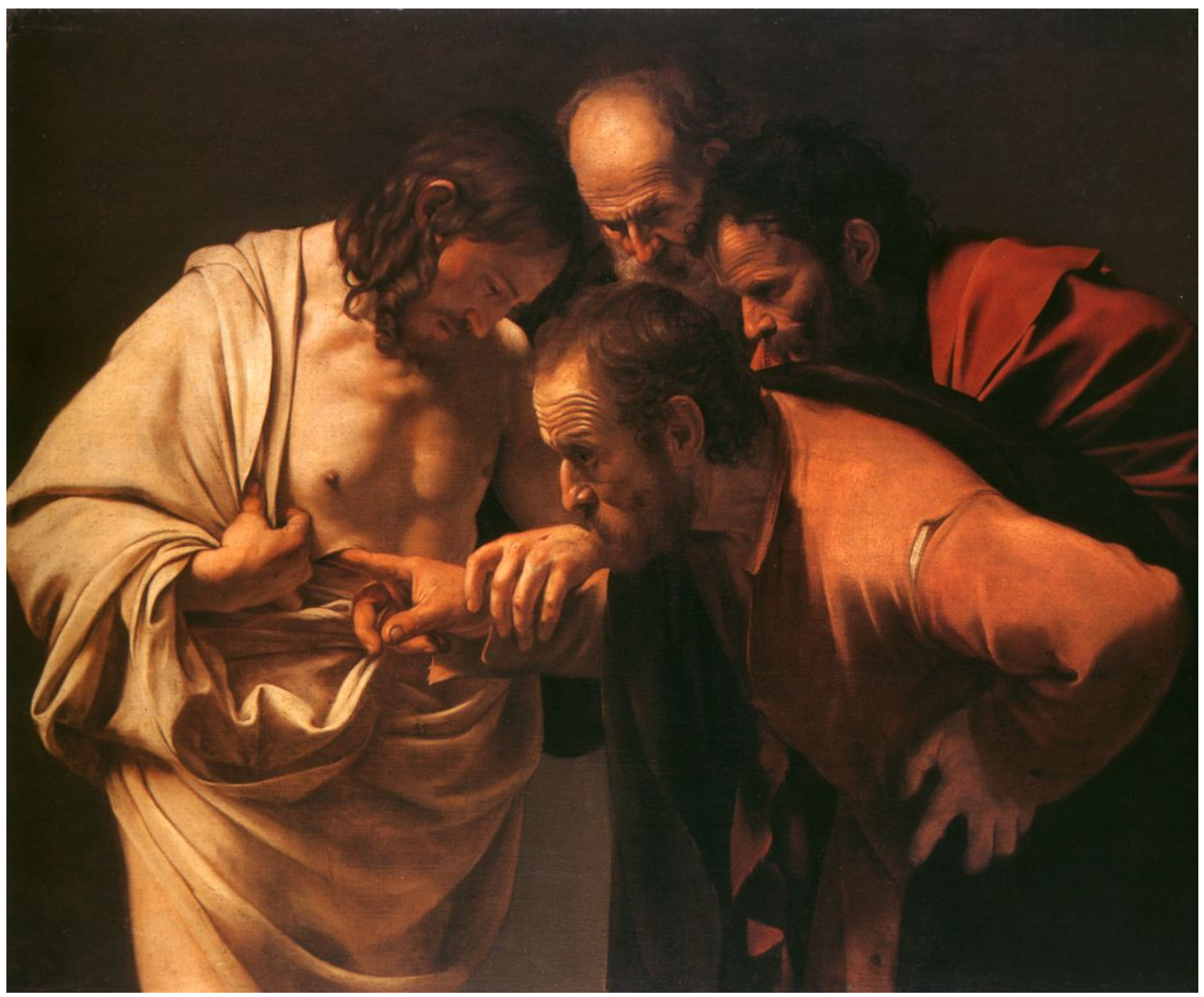

FIGURA1 - Michelangelo Merisi da Caravaggio, A incredulidade de São Tomé, 1602, óleo s/tela, 107 $x 146 \mathrm{~cm}$, Palais von Sans-Souci, Potsdam.

Mas não nos adiantemos em demasia. Queremos compreender esse saber trágico por outra perspectiva. Então, sugerimos que embarquemos no vórtice de Poe, já que a queda é inevitável, e, obliquamente, pairemos sobre outro tempo, porque o espaço seguro em que nos encontramos agora foi eliminado. Alguma 
vontade misteriosa nos faz querer cair mais. Cair para o centro. Cair mais profundamente.

\section{A FERIDA}

Geralmente, temos a ideia de que uma imagem antiga como Aincredulidade de São Tomé, 1602, de Caravaggio dirá pouco sobre a época em que vivemos. Aceitamos, facilmente, que uma imagem de um período anterior ao nosso dirá muito sobre o período em que ela foi feita. Isso não deixa de ser correto. No entanto, curiosamente, imagens concebidas em tempo muito distante do nosso, muitas vezes, atualizam-se. A imagem, enquanto objeto, certamente é a mesma. A pintura Aincredulidade de São Tomé, feita nos 1600, visualmente não nos é diferente da época de Caravaggio. Mas o olhar que depositamos sobre essa certamente o é. Que inquietações essa obra nos traz? Como cintila essa obra no presente? Sabemos que é uma imagem pictórica. Mas poderá ser pensada como fotografia? De que maneira essa imagem pode nos suscitar uma vertigem?

Trabalharemos essa imagem da mesma maneira que trabalhamos os fragmentos do conto de Poe: como fotografia. O nosso argumento para tratá-la como fotografia é que Caravaggio pensava em termos de luz. No tópico anterior a fotografia esteve atrelada à ação. A um instante que se desenrolava no espaçotempo. Dessa forma, todo instante foi também fotografia. Neste tópico, veremos que a ação está congelada. O instante existe, mas ele é tão ínfimo que chega a nós já imobilizado. É um passado que se presentifica ou um futuro carregado de nostalgia. Mais uma vez a ação estará suspensa no tempo-espaço.Também trataremos a arte de Caravaggio como pertencente à modernidade. Pois, por modernidade, entendemos o período que se inicia na Renascença quando o homem passa a estar no centro de suas representações, ao contrário de como era na época medieval quando Deus é que ocupava esse lugar, e vai até o período das chamadas vanguardas modernistas, onde o sujeito continua centralizado e polarizado com o mundo.

Em Descida ao Maelström, o espaço e o tempo pareceram trocar de lugar. Em $A$ incredulidade de São Tomé será o visível e o tangível que se intercambiarão de forma terrificante. Aqui, a vertigem será suscitada por uma dúvida, por uma 
incerteza quanto àquilo que percebemos. Já entendemos como a vertigem, suscitada por um ocultamento do espaço, faz colapsar o real e o imaginário. Agora, tentaremos entender como a aparência, que para nós é a escrita da luz, a mais pura verdade sobre todo o visível, tornar-se-á o véu mentiroso, o qual nos conduzirá em uma experiência da queda.

Nosso método será a comparação entre aparência e realidade. Entre visibilidade e tangibilidade. Entre certeza e incerteza. Entre terror e beleza. Entre realidade e fotografia. Entre metáfora e metonímia. Entre espaço interno e espaço externo. Entre o método de Poe e o de Caravaggio.

Da mesma maneira que Poe, Caravaggio interessou-se por temas sombrios. Temas em que o humano é sinônimo de dor e angústia. A tradição, desde o Renascimento, procurava representar figuras e objetos com alto grau de estilização. O espaço, dominado a partir da perspectiva artificialis ${ }^{1}$, era o palco onde se colocavam figuras "divinas". Caravaggio, indo na contra mão da tradição de sua época fez do "divino", dos temas bíblicos e dos temas mitológicos, um retrato da vida cotidiana e banal. Buscando, nas ruas, pessoas comuns para servirem de modelos para seus quadros.

Longhi (2012) sugere que a pintura de Caravaggio estaria inserida numa tradição de pintores lombardos, que diferentemente dos florentinos e dos venezianos, trabalharam o espaço em termos de planos de luz e não de construção perspectiva como os primeiros e nem de tonalismo cromático como os segundos. $\mathrm{O}$ corpo em Caravaggio é antes luz que objeto a ser modelado pela mão do artista. É antes imagem que matéria escultórica. É antes 'realidade', ou seja, luz, que estilização. É antes imobilidade que fluxo temporal. É antes superfície que espaço em perspectiva. Isso, pode-se inferir pelo método empregado por Caravaggio na

\footnotetext{
${ }^{1}$ Leon Battista Alberti (1404 - 1472) teorizou em seu tratado sobre pintura conhecimentos relativos a representação plástica do espaço. Na época, uma série de outras formas de representação do espaço existiam tais como: a perspectiva angular, a inversa ou a curvilínea. Contudo, a forma que se impôs na Renascença foi a perspectiva artificialis ou central, porque a tradição logrou identificar essa construção perspectiva com o efeito de "real". (MACHADO; ARLINDO, 1984, p.66).
} 
produção de uma imagem. O pensamento tradicional sobre arte pensava o corpo como um objeto a ser modulado em claro-escuro. A mão e o olho mantinham uma cumplicidade. O claro-escuro modula as figuras, concebe-as como objeto táctil destacado do espaço, e, depois insere-as num espaço em perspectiva, que nada mais é que uma maneira entre outras de conceber o espaço. Era um espaço estável onde os corpos e objetos encontravam-se em segurança.

Caravaggio partiu diretamente do duplo da realidade. Espelhos e projeções interessaram-lhe mais que esboços a partir de modelos vivos. Para produzir suas imagens ele pintou a parede de seu ateliê de preto, de maneira que, deixando vazar um facho de luz sobre as coisas e corpos, construía um plano de luz. Desse modo, pintava as partes dos corpos e coisas que a luz incidente o deixava ver. Ou melhor, pintava a partir da projeção de figuras e coisas mais do que a partir delas mesmas. Diferentemente da tradição de sua época, o artista pintava não diretamente e ao natural, mas através de espelhos e com uma iluminação artificialmente dirigida. Dessa maneira, buscou um instante único, estático e, portanto, já nostálgico e irreversível. Os aspectos da vida e da morte estão estranhamente entrelaçados. A ação na imagem é um fragmento congelado de 'realidade'. Uma agonia perene. $O$ pensamento de Caravaggio nesse sentido é fotográfico assim como também é trágico. Luz e sombra confrontam-se dramaticamente. Mas, também é difícil não perceber em Caravaggio um amor obsessivo pela carne. O corpo, em Caravaggio, é carne corruptível. Assume forma plena, elevada, bela, mas decai; decompõem-se. É imobilidade e rigidez, ao mesmo tempo em que é forma mutável, fluxo incessante da matéria. Seus bacos (Figura 3 e 4) oscilam entre a saúde e a doença. Entre o prazer e a dor.

Seu método é fotográfico, na medida em que se interessa por um instante ${ }^{2}$ especular. A imagem fotográfica

\footnotetext{
${ }^{2} \mathrm{~A}$ noção de instanteempinturafoiteorizadopor G.E Lessing emseutratadoLaocoon (1776). O teóricoacreditavaque podia extrair de um acontecimentoseumomentomaissignificativo. À essemomentodeu o nome de instantepregnante.Difícilnãopercebersemelhançacom a ideia do instantedecisivo de Henri-Cartier Bresson. Com issonãoqueremosdizerque as imagens de Caravaggio nãoeramencenadas.Nessesentidodifere do instantedecisivo de Bresson. Apenasqueremosevidenciarqueaideia de instante é relativa.
} 
é o contrário da simultaneidade do tempo real. [...] O Fluxo visual só conhece a mudança, e a imagem não tem sequer tempo de se tornar imagem. [E para que isso aconteça] é preciso primeiro que se torne uma, e isso só pode ser feito na suspensão da operação tumultuosa do mundo e numa estratégia de despojamento. Substituir a epifania triunfal do sentido pela epifania silenciosa do objeto e de suas aparências (BAUDRILLARD; JEAN, 2002, p. 144).

Estratégia antiga, clássica, platônica, em que "a imagem está na interseção da luz vinda do objeto e da luz vinda do olhar" (BAUDRILLARD; JEAN, 2002, p. 145). Estratégiada qual Caravaggio tornou-se mestre, e a qual tem por finalidade resistir sempre ao ruído, ao fluxo do movimento, resistir ao tempo e estabelecer o silêncio e o 'segredo do mundo'. Estabelecer a verdade intrínseca do mundo a partir de sua aparência silenciosa. Revelar o 'segredo do mundo' é um crime contra a natureza. E, só poderá nos revelar o 'segredo do mundo' aquele que tem "sabedoria" (NIETZSCHE W.; FRIEDRICH, 2004, p. 63). Assim como Sileno, que revela ao rei Midas que a grande tragédia da sua raça é ter nascido; é ser filha do acaso e da dor. A sabedoria em questão é a sabedoria trágica e que tem como antítese o conhecimento científico dos dias modernos. O sábio que comete um crime contra a natureza é o xamã ou curandeiro, é a figura grega do sátiro barbado, é o deus Dioniso. É a arte do sombrio. O conhecimento de Dioniso é o da interioridade do corpo. Paglia (1994, p. 100) diz que o princípio violento do culto de Dioniso é o sparagmós que em grego quer dizer rasgar, despedaçar, estropiar. Nessa religião pagã, o visível reduz-se ao tangível. "Na identificação dionisíaca, o espaço entra em colapso. O olho não pode manter a perspectiva. Dioniso não pode ver a floresta por causa das árvores" (PAGLIA; CAMILLE, 1994, p.100).

Caravaggio, dessa maneira, é duas vezes criminoso. Uma perante a sociedade, quando assassina um rival seu, e outra perante a 'natureza', quando revela aos homens a sabedoria de Sileno a partir do legado de sua obra. No final, teremos todos o mesmo destino! É o que nos ensina o saber trágico. Em Caravaggio, o espaço é uma boca negra prestes a tragar suas figuras de volta à escuridão. A brutalidade da aparência de suas imagens aparece como um instantâneo, cuja beleza não se separa do horror, onde luz e sombra mantêm uma estranha união. 
Em Descida ao Maelström, o conhecimento dessa sabedoria trágica aparece na ação do pescador, o qual se salva porque compreende que o que separa o desespero da diversão é uma linha muito tênue. Mas, em $A$ incredulidade de São Tomé, de Caravaggio, como chega a nós seu saber trágico?

Vejamos nosso objeto. É uma imagem em termos tradicionais! Um objeto papável, concreto, existente na linha do tempo histórico. Trabalhamos com uma imagem real. Uma pintura que data do início dos anos de 1600 , cujo título é $A$ incredulidade de São Tomé e cujo autor ficou conhecido pelo nome de Caravaggio. O que temos aí, por outro lado, não é só uma imagem. Junto a ela vem um título, uma assinatura, um contexto histórico. Dificilmente conseguiremos deixar isso de lado. No entanto, o que nos interessa, aqui, é como essa imagem pode nos colocar em queda.

Comecemos pelo protagonista da imagem. Tomé é o apóstolo relegado da bíblia. Aquele que pecou duvidando da santidade de Cristo. Para Tomé, o corpo jamais poderia retornar do mundo dos mortos. Pois, espiritualidade e carne estavam separados e nem mesmo Jesus Cristo poderia romper com essa lei. Tomé é o sem fé. Precisa tocar para 'ver'. Tomé duvida de seus olhos, mas não de sua mão. A ciência 'profana' que indaga o mundo material poderia ser representada nos dias de hoje por esse apóstolo incrédulo. A dúvida é mestra orientadora da ciência. Sem dúvida não há ciência. Mas será a dúvida de Tomé a mesma da ciência?

Por duvidar, Tomé, diferentemente dos outros apóstolos, não mereceu um evangelho próprio. Os evangelhos sinópticos são textos nos quais se mantem um mesmo ponto de vista, como o de João ou Mateus, por exemplo. O que sabemos de Tomé encontra-se em passagens desses evangelhos. No entanto, em 1945, foi encontrado na biblioteca de NagHammadi um evangelho perdido, o qual tem sido atribuído a Tomé. Esse evangelho é o único que não segue a estrutura dos demais evangelhos. É um documento gnóstico, ou seja, busca outro tipo de conhecimento, no qual Deus não estaria acima dos Homens, mas entre eles, ou dentro deles, diferenciando-se do que a tradição cristã nos ensina sobre Deus. Gnose vem do grego Gnosis que significa conhecimento; mas, um conhecimento que não é racional, científico, filosófico, teórico ou empírico, não é a episteme dos gregos. 
Tomé ou Thomas vem do aramaico Tau'ma que traduzido para o grego é didymus, e traduzido para português é dídimo, que significa gêmeo. Dídimo também quer dizer aquilo que cresce aos pares ou que se divide em dois lobos, que tem duas partes simétricas. Ficaremos com a ideia de que o nome Tomé carrega essa ambiguidade quanto ao seu significado. Tomé aqui, então, está sendo relacionado com a ideia de duplo. Uma relação ambígua entre ver e tocar. Entre dúvida e fé. Entre conhecimento científico e conhecimento intuitivo. Entre a aparência objetiva das coisas e a latência que essa objetividade pode ocultar.

Esqueçamos por um momento informações históricas e concentremo-nos apenas na imagem. Voltemos à imagem do vórtice sugerida por Poe. De que maneira encontramos esse sentido espiralado em Aincredulidade de São Tomé? Escolhamos um ponto qualquer nessa imagem. Sugerimos a ferida de Cristo. Continuemos partindo da literalidade da imagem; daquilo que vemos: a ferida, o ponto nodal. Há algo atrás dela? Avancemos com cautela. Estamos sobre a superfície da imagem. Sobre sua objetividade visual. Podemos apontar para ela, mas não podemos tocá-la. Nosso dedo, diferentemente do dedo de Tomé, não toca, apenas aponta. Percebemos que a ferida de Cristo não sangra. É um estranho buraco negro. Então, recuemos a partir da ferida de Cristo às outras partes da imagem. Nosso dedo segue, acompanhando cada minúcia da imagem. Ao redor dessa ferida há um núcleo de mãos que se aglutinam. Nossa percepção, a visão, quer estar nas pontas dos dedos. O manto branco de Cristo segue a ordem concêntrica dos espirais. Curvando-se todo ao redor da ferida. As cabeças vêm a formar um outro núcleo espiralado convergindo à ferida, aderem-se em círculo, assim como as rugas na testa dos apóstolos sugerem ondas concêntricas de tensão. Agora, mais distantes do ponto nodal, percebemos o conjunto dos quatro corpos em meio ao fundo negro. O negro do fundo e o negro da ferida facilmente intercambiamse. São estranhamente feitos de uma mesma matéria escura. Tato e visão estão demasiadamente aproximados. Aquilo que delimita a interioridade da exterioridade já não pode ser precisado. Mais uma vez estamos de olhos cerrados, como o pescador de Poe diante do turbilhão. A visão não pode ser um sentido onipresente. Com o Tomé caravaggiano, o tato, a interioridade e a sombra reivindicam sua parcela de autoridade no equilíbrio do mundo. 
Mas onde está o 'real' nessa imagem? O que é visível e o que é tangível? O método de Caravaggio para nos lançar na interioridade do corpo foi a repetição de formas circulares, sugerindo a indistinção entre o dentro o e fora. A ferida de cristo é o dentro da mesma maneira que é o fora. Não há começo, assim como não há fim. Pois, todo círculo é uma via de mão dupla. De onde quer que partamos nessa imagem chegaremos sempre ao mesmo lugar: um estranho buraco negro onde não há visibilidade. É o movimento sugerido pelas formas circulares colocando-nos aquém e além delas, que nos sugere um significado. Mais uma vez, assim como em Poe, o real não pôde ser representado. Somente sugerido. Cinge-se o vazio.

Barthes (2008) fez uma distinção entre duas maneiras de se olhar uma imagem. A uma ele chamou de studium, à outra de punctum. O studium é aquilo que chega a nós culturalmente. O studium é encontrado por nós. Dizemos: isto é um rosto e o consenso geral concordará comigo que o é. O punctum não pode ser encontrado. "É ele que salta da cena, como uma seta, e vem trespassar-me" (BARTHES; ROLAND, 2008, p. 35). Nessa imagem de Caravaggio, a ferida assume a condição de studium ao mesmo tempo em que de punctum. Essa imagem de Caravaggio é a aparência congelada das formas. É o véu mentiroso da objetividade do instantâneo fotográfico protegendo-nos da realidade sombria do mundo. Trabalhou-se, aqui, a dúvida de Tomé como um choque. Como um trauma. O que sabe Tome está, ou foi, reprimido.

Nietzsche (2004)sugere que a vida, para suportar a si mesma, precisa da arte. Os dois princípios da vida, assim como da arte, são o apolíneo e o dionisíaco. O apolíneo é o universo das aparências, do sonho, da ilusão, do véu que encobre a realidade primeira e que nos protege da cegueira que aquela indubitavelmente causar-nos-ia caso o véu não existisse. Dioniso, como foi sugerido, não pode ver porque seu campo de ação é o da interioridade. O momento trágico é quando Dioniso vem descortinar o véu das aparências de Apolo, o qual serve para nos proteger do real. Nietzsche, chama a nossa atençãoparao fato de "que atrás da realidade em que existimos e vivemos, se esconde outra muito diferente, e, que, por consequência, a primeira não passa de uma aparição da segunda" (NIETZSCHE W.; FRIEDRICH, 2004, p. 20). Contudo, este mundo das aparências é a nossa realidade de todos os dias: do trabalho, da família, da linguagem; sem a qual o homem seria apenas instinto e irracionalidade. 
Caravaggio é apolíneo na medida que se interessa pelo instante congelado do mundo. A linha apolínea, mestra orientadora da forma, possibilita-nos ver a partir da luz incidente. A necessidade de verossimilhança de Caravaggio é vontade apolínea dirigida sobre o caos do mundo. Mas Caravaggio intui que a realidade primeira da qual fala Nietzsche é outra bem diferente. É o caos apavorante onde a individualidade das formas e do Eu do homem não encontram autoridade.

Caravaggio, diferentemente de muitos artistas de sua época, não quer endireitar o mundo. Não quer estilizar ou embelezar. Quer um retrato da vida nua e crua. As maçãs de suas naturezas mortas estão maduras e saborosas. Mas, o artista, não esquece de retratá-las apodrecendo (Figura 4). O artista, a partir do choque da visão patética do mundo, leva-nos a ver o imponderável. Embriagados em um caos de sensações e pensamentos somos levados a nos aniquilar no total esquecimento de nós mesmos e descobrimos a certeza de Tomé. Estamos sós. $E$, a carne é corruptível. O Eu findará, perecerá junto a ela. Independentemente de nossas tentativas, de nossa vontade apolínea, de nossa arte, de erigi-lo sobre os outros e o mundo.

Aqui, quisemos pensar o tangível a partir do visível. A partir da pura aparência das coisas, da visão especular do mundo, chegamos à mudez murmurante das coisas. Algo saltou do quadro e veio nos atingir. Fisgando-nos para a escuridão de seu interior. Encontramos a nós mesmos, que pensávamos ser o outro, alheio, distante e separados de nós. A experiência da queda, neste tópico, foi o encontro do sujeito consigo mesmo. Do encontro com a verdade sombria do mundo, na suspensão aterrorizante do Eu. 

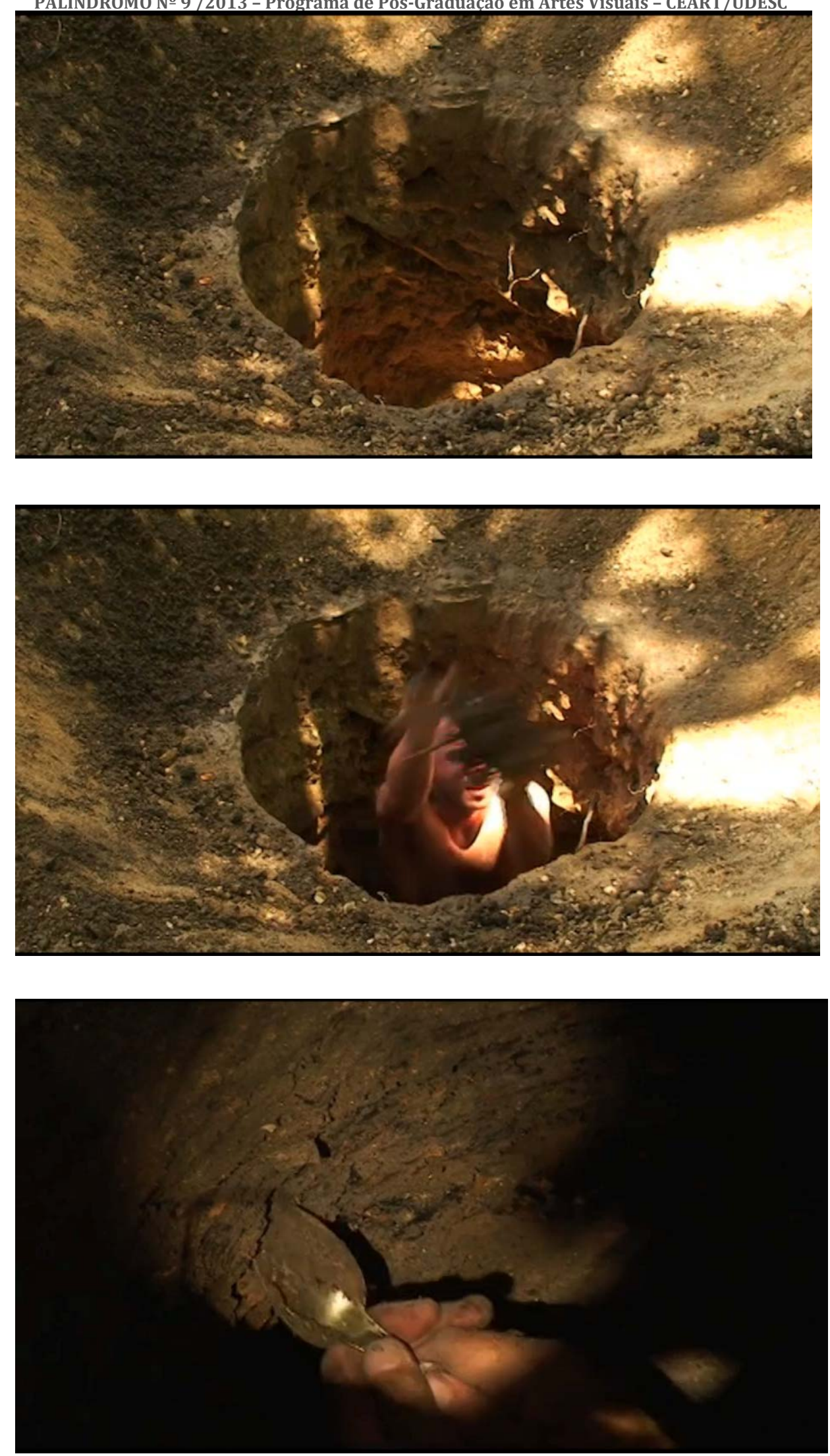

FIGURA 2 - Rodrigo Braga, Sal e Prata, 2010, vídeo-performance. 


\section{A CAVA}

$\mathrm{Na}$ arte caravaggiana a identidade é uma luta, onde o Eu procura erigir-se a partir do real caótico de Dioniso. Toma-se distância e impõe-se. De uma forma ou de outra o Eu está centralizado. Na solitude de seu ateliê, Caravaggio investe hora a hora contra a escuridão que ameaça tragá-lo. Na modernidade, o Eu do artista é uma mônada, coesa e inquebrantável que deve ser protegida a qualquer custo. A morte é parcialmente vencida. O corpo finda. Porém, o Eu encontra sua imortalidade ficando para a História. Se, em Aincredulidade de São Tomé, procurando um outro, encontramos a nós mesmos, é porque nosso olhar é contemporâneo.

$\mathrm{Na}$ modernidade,o Eu acreditava poder alicerçar-se sobre terreno sólido e estável. Na contemporaneidade, é essa solidez e estabilidade que estão sendo colocados em questão. Diz Bragança de Miranda:

Presença e ausência, efémero e permanente, hard e soft, alto e baixo, tudo se mistura: meras divisórias da vida, ao mesmo tempo arbitrárias e fatais. Todo o problema está na inconsciência em que se mantêm, mesmo no seio das teorias que as criam ou dão a ver. É esse seu centro de "cegueira". Só podemos mover-nos passando por essas barreiras, critérios, medidas, mas não podemos fazê-lo livremente sem atentarmos à oscilação que todas as "medidas" contêm (BRAGANÇA DE MIRANDA A.; JOSÉ, 2006, p. 10-11).

A arte contemporânea a par desse problema transforma-se, e trabalha a questão da identidade do sujeito de maneira diversa à da modernidade. O Eu, mais consciente da relatividade das coisas, não se isola de modo a enfatizar a relação de oposição entre o Eu e mundo. O sujeito contemporâneo não quer, ou não pode tomar distância. A intimidade do sujeito foi conduzida ao seu extremo; e houve uma inversão inesperada. Pois, "o máximo da intimidade é, como disse Lacan, a extimidade" ${ }^{3}$ (FORBES; JORGE, 2013)

Veremos que o vórtice não opera apenas no sentido de uma experiência do "sem fundo" como em Poe. Tampouco intercambiará o dentro e o fora, no sentido do Eu que está fora e encontra a si mesmo no dentro, no silêncio de si mesmo, como

\footnotetext{
3“'Lacan propõem o conceito [de extimidade] para substituir a intimidade falsa. Percebe, ele, que na verdade nos orientamos e nos decidimos pelo cálculo dos outros, ou seja, pelas conclusões que tiramos em relação aos outros" (FORBES; JORGE, 2013).
} 
no Tomé de Caravaggio. Não será uma fenda prestes a nos tragar. Pois, já fomos tragados. O sentido ainda é o fundo e é o dentro, o profundo de nós mesmos. Mas, inesperadamente, encontramos um outro ali, a nos espreitar.

Já entendemos como a realidade pode ser um véu mentiroso construído por nossa vontade. Com Nietzsche e Caravaggio vencemos essa etapa. Sabemos que todo o visível é uma construção nossa. Mera ilusão. Fotografia não é mais metonímia como em Caravaggio ${ }^{4}$. Não é um duplo do visível. Não somos mais ingênuos! Voltará a ser metáfora como em Poe? Estamos na era digital onde toda simulação é possível. Todo o real questionável. A fotografia é tudo menos um duplo ingênuo do real. Será duplo do imaginário?

Neste tópico, analisaremos um vídeo de Rodrigo Braga, cujo núcleo de discussão aponta para a fotografia e para o sombrio como tema. Diferentemente de Caravaggio, Braga não busca o duplo da realidade. Mas se interessa por ela. Interessa-se tanto que gosta de manipulá-la. De trabalhá-la a ponto de transformá-la em algo mais real que o real. A natureza e a cultura, a humanidade e a animalidade, o sujeito e a linguagem, são temas frequentes nos trabalhos de Braga. Em seus primeiros trabalhos, a manipulação digital foi a opção para pensar as relações entre sujeito e natureza. Entre o real e o imaginário. Como Fantasia de compensação (Figura 5)de2004, onde o artista mostra-nos uma estranha relação entre humanidade e animalidade. Em seus trabalhos seguintes o embate entre sujeito e natureza continua. E a manipulação digital dá lugar à encenação. Em outro trabalho com um bode, um vídeo intitulado de Tonus III (Figura 7), de 2012, Braga amarra seu corpo ao do animal parecendo retrabalhar o que já fizera em Vontade I (Figura 6), de 2007, trabalho no qual o artista amarra o corpo morto de um pássaro ao de outro vivo, que tenta desesperadamente desvencilhar-se do fardo.

\footnotetext{
${ }^{4}$ Flores (2011) faz uma distinção entre duas maneiras de conceber a fotografia. A primeira é metonímica, ou seja, tem a função de espelhar a realidade do mundo material. A autora faz alusão a imago romana: figura de cera que se moldava a partir do cadáver de determinada pessoa. A segunda é metafórica, ou seja, cumpre a função de semelhança e não de contingência como na precedente e, portanto, tem caráter ideal (platônico), ou projetivo. Apesar do instante em Caravaggio, por um lado, ser ideal, por outro é metonímico porque se constrói a partir de uma visão especular.
} 
Em trabalho realizado recentemente, Sal e Prata de 2010, um vídeo de cerca de nove minutos, Braga cava um buraco com uma colher de prata e as próprias mãos durante quinze dias. Junto ao vídeo um manuscrito, onde o artista relata que após uma noite mal dormida decide anotar o sonho que tivera:

Tão angustiante foi a sensação que tive ao me deparar com a decisão obstinada de Dalvinha em cavar aquele buraco em direção às profundezas. Ela chorava mais estava certa, muito certa, de sua vontade aparentemente sem sentido: apenas cavar, cavar e aprofundar por tempo indefinido... (BRAGA; RODRIGO, 2010).

A vontade de Dalvinha também fora a nossa, quando no último parágrafo do primeiro tópico, quiséramos cair mais; cair mais profundamente. Braga relata-nos que, em seu sonho ficara impressionado com a empreitada de Dalvinha em cavar um buraco tão profundo, e, que só se preocupava com sua saúde e em the apoiar em sua jornada. Pois, Dalvinha "não olhava para cima, não queria dormir, não pedia para sair" (BRAGA; RODRIGO, 2010). Após o sonho, Braga decide cavar um buraco, tal qual fizera Dalvinha. Diz não se lembrar com que instrumento ela cavara um buraco tão profundo. Decide-se, então, por uma colher de prata que está há muitas gerações em sua família. Pensa, Braga, que o ato de cavar tal buraco com uma colher remete-lhe a desesperada insanidade dos presidiários. E, por fim, pergunta-se se poderia interromper o destino daquela colher. Se poderia contar outra história.

Voltemos às nossas velhas questões. Que instante é este? Que sentidos podemos obter dessa ação de Braga? De que maneira a ação está suspensa? A imagem apresenta-se como acontecimento. Vemos o desenrolar da ação. Pouco a pouco vemos Braga cavar. Abrindo um enorme buraco negro no solo. Uma fenda circular. Feita com muito esmero. Uma fenda cujo interior temos dificuldade em ver. Não sabemos aonde essa ação nos conduzirá. Suspeitamos! Percebemos cortes nessa ação. Havíamos descoberto em nossa pesquisa que a ação teve um tempo de duração de quinze dias. Mas ao que temos acesso no contato direto com a obra são cerca de nove minutos de ação. Não há continuidade temporal. No entanto, o recurso da montagem permite-nos experimentar essa sensação. A montagem é um hiato, ao qual ficamos alheios, e que nos permite entrar em contato com uma 
realidade construída. Ela marca um tempo; pontua e enfatiza o tempo imaginário fazendo com que o percebamos como real. Nada parece estar congelado aqui. Tudo parece fluir, ininterruptamente, até o momento em que Braga para; joga sua colher secular de prata e a enterra. Algo está findo. É o instante último de um objeto secular. Como se morre aqui? Que pesadelo é esse criado por Braga? Que tragédia subjaz aqui?

Diferentemente de Poe, que lançou-se em águas lúgubres, e delas quis retirar algo valoroso. Diferentemente de Caravaggio, que na escuridão de seu ateliê buscou lampejos de luz e desejo, fazendo disso uma luta simbólica contra a morte. Braga também luta; silenciosamente. Mas seu palco de ação é a terra. Olha-a diretamente. Fita-a. Tem coragem. Mas, somente, porque sabe que está armado. Porque, antes de tudo, é um fotógrafo. Alguém que pode fazer com que qualquer coisa seja eterna. Sabe que mente. Sabe que apela. Sabe que encena. Sabe que não é herói.

A fotografia de Braga é digital. Uma arma supra-humana, dada por um deus ex-machina, capaz de alterar qualquer história. Arma profana que apaga e desenha qualquer verdade. Que faz de qualquer sonho uma realidade. Que faz da realidade um sonho dantesco. É a história secular da fotografia analógica que Braga simbolicamente enterra em Sal e Prata. Seu sal e sua prata. Sua verdade metonímica; jaz, aqui. Inventamos um mundo novo. Inventamos o pixel. Não sabemos mais o que somos nós, e o que é o mundo. O que é natureza e o é que e cultura.

François Soulages (2010), seguindo o pensamento de Nietzsche sobre verdade e realidade, traz essa questão para a fotografia."Somos devotos diante do real inventado, pois queremos imobilismo e não fluxo, eternidade e não tempo, vida e não morte, parada e não movimento. Como se a verdade fosse um ser e não a característica possível de um juízo"(SOULAGES;FRANÇOIS, 2010, p. 110).A recepção fotográfica, dessa maneira, é sempre uma interpretação.

A arte, depois da disputa entre a luz e a treva, encontra um campo onde o pathos, exila-se; e dá espaço ao silêncio ruidoso do vazio contemporâneo. Nesse novo espaço, o apolíneo e o dionisíaco não brigam. Tudo está misturado. Vilém Flusser (2008) chamará esse lugar de reino das mães imutáveis. O Eu do passado 
sofria abalos, mas não encontrava sua dissolução. De uma forma ou de outra, o Eu e o outro (mundo) precisavam estar em guerra constante. Diz Flusser sobre este Eu moderno.

O nosso Eu é manifestação de sede. O nosso Eu é uma deficiência, o nosso Eu é doença. Pensar é doença e viver e doença. Aflitos por essa sede, por essa deficiência, por essa doença que é o Eu, sofremos. É devido a esse sofrimento que acreditamos poder pensar e poder viver, é por isso que querermos. Querer é sinônimo de sofrer, e vontade é sinônimo de Eu (FLUSSER; VILÉM, 2008, p. 197).

$\mathrm{Na}$ contemporaneidade, o Eu procura o outro (o mundo) para se fundir. E confunde-se com este, não sabendo mais o que é mundo e o que é Eu. Essa é sua tragédia. Sabemos que o mundo, como o conhecemos, é invenção nossa. Podemos inferir que todo conhecimento é relativo e não passa de construção de nossa vontade.

A mente, dilacerada pela luta de Apolo e Dioniso pede a morte. Exausta pelo lusco fusco da luz e da treva, pede resignada o silêncio eterno. Silencia-se, nesse clima prateado e melancólico. O que nos resta agora que parecemos estar preso com um outro que detestamos, mas sem o qual não podemos viver? Esse outro é alguém que suspeitamos conhecer. Alguém que está a ocupar o espaço da cava junto de nós. Nesse espaço de um só, vem a nós esse outro, do qual não podemos nos separar. Queremos expulsá-lo, mas ele nos atrai. O que nesse vazio se faz tão cheio, tão completo? Ora, é ela: a fotografia; a imobilidade outrora tão desejada, e agora tão repelida.

Freud, em Mais Além do princípio do prazer, fala deste outro, ao mesmo tempo desejável e indesejável. É o instinto de morte.O psicanalista, no final de seu pensamento, percebe que a oposição entre o inconsciente e o consciente não pode se manter; pois, a ideia de pulsão, que a princípio é de mudança e progresso, alterase para "uma tendência própria do orgânico vivo à reconstrução de um estado anterior" [...] (FREUD; SIGMUND, vol. 8, p.289).Dessa maneira, os instintos sempre conservadores só repetiriam um mesmo caminho que leva à morte, isto é, a um estado inanimado que se supõe ser o início da vida, e ao qual eles desejam voltar. 
O fato de o fim da vida ser um estado nunca alcançado anteriormente, estaria em contradição com a Natureza, conservadora dos instintos. Dito fim tem antes de ser um estado antigo, um estado de partida, que o animado abandonou alguma vez e para o qual tende por todos os rodeios da evolução. Se, como experiência, sem exceção alguma, tivermos de aceitar que todo ser vivo morre por fundamentos internos, voltando ao anorgânico, podemos dizer: $A$ meta de toda vida é a morte. $\mathrm{E}$, com igual fundamento: $\mathrm{O}$ inanimado existia antes do animado (FREUD; SIGMUND, vol. 8, p. 291292).

O Eu é a contingência que se entrelaça com a necessidade do instinto. Assim, o Eu é imobilidade buscando a mobilidade da vida. O Eu, como diz Freud, é uma vesícula calcinada, resistente à avalanche de estímulos do mundo. Essa vesícula calcinada deseja a imortalidade e a mobilidade. Dois princípios antagônicos. O Eu quer interromper o fluxo continuum da vida que são os instintos de conservação da espécie, porque estes Ihe causam tensões, as quais na maioria das vezes, não pode suportar, e, portanto, reprime-as. A contradição do Eu é querer eternidade e mobilidade ao mesmo tempo. Mas, o que o Eu no fundo deseja é a imobilidade. É voltar a um estado antigo de prazer sem esforço. Mas, a imobilidade é a morte. E isso ele não quer. Então, está fadado a repetir-se sempre, buscando sua identidade primeira que um dia perdeu. Essa experiência de perda leva-o a ter uma atividade repetitiva, que supostamente controla a situação. Dessa maneira, repetir é morrer. É voltar ao estado primevo de onde surgimos: a imobilidade do nirvana, reestabelecimento da matéria anorgânica. Contudo, o Eu repete-se de forma sempre diferente. Assim, gera o continuum de sua própria existência.

O ato de fotografar, diz Dubois (1994, p.163), é da ordem do performativo. E a compulsão à repetir é algo característico desse processo. Fotografamos um fenômeno uma, duas, três vezes, e assim sucessivamente. O que buscamos? Queremos, provavelmente, imortalizar, deter o fluxo do tempo em nossa memória. Queremos fixar, eternizar algo que nos é precioso. Em Sal e Prata, cada ação de retirar um punhado de terra é capturada numa pequena fração de segundos e reconstruída a partir de instantes dispostos sucessivamente. São os fotogramas: instantes congelados de uma ação que, postos em conjunto, nos dão a ideia de continuidade. Mas entre um instante e outro há um lapso, o qual não se pode capturar. Existe um buraco, uma ausência implícita e da qual, sem nos darmos 
conta, sentimos falta, e a qual queremos restituir. São os hiatos da montagem. Podemos enganar nosso olhar, montando esses instantes e tendo a sensação de continuidade. No entanto, a ausência permanece lá, escondida, esperando nosso retorno. De maneira que sempre vamos querer voltar ao estado anterior que precedeu toda ação de cavar e enterrar. Queremos voltar à motivação inicial.

Essa breve reflexão sobre a natureza da montagem leva-nos novamente ao tema de Sal e Prata: a ausência. Sal e Prata é a redundância de uma ausência. Cada cavada de Braga é uma tentativa de restituir o instante perdido, buscar a essência do instante fotográfico. Aqui, a imagem-movimento (vídeo) aparece como exercício da compulsão de uma repetição de um instante primeiro.

Assim como os instantes que vimos nos tópicos precedentes, o instante em Sal e Prata também se eterniza. Não a partir do colapso do espaço e do tempo como em Descida ao Maelström, nem a partir do embate entre luz e treva ou no embate entre visibilidade e tangibilidade que se apresentou na agonia paralisante de um instante último em $A$ incredulidade de São Tomé. Mas a partir da repetição de um instante único, que se revela na ressonância de inúmeros instantes. $\mathrm{Na}$ redundância de tal ato sequencial, emerge o perpétuo do instante fotográfico. Pois o estático, o anorgânico, não guardaria em si todas as potencialidades do vivo?

O instante fotográfico é tanatócrito, ou seja, cumpre fazer a comunicação com um 'outro', com nossa alteridade radical que é a morte. Aqui são os mortos, ou o instante de uma ausência, que, paradoxalmente, vêm nos falar do mundo do animado. Quando olhamos uma foto, quer dizer, quando olhamos para uma fatia cortada do tempo contínuo, indubitavelmente queremos reviver em nossa mente aquilo que vemos. O que foi cortado do tempo é por nós revivido. A ação do passado torna-se presente e futura a partir de nossas projeções. Dessa maneira o instante fotográfico, primeiramente, faz do vivo um morto quando recorta do tempo contínuo um instante. E seguidamente desse instante morto e, portanto, estático, um vivo, quando rememoramos o morto. Rememoração essa que nunca é igual à primeira porque se atualiza e, assim, já vive um presente-futuro. Pois é o que fazemos sempre ao olhar uma foto: revivemos o momento que foi capturado. Dessa maneira o instante fotográfico guarda em si a potência de todos os tempos idos e 
vindos. O instante fotográfico é passagem para além e aquém de nós mesmos. É o nosso encontro com nossa metade esquecida, e eternamente desejada.

O método de Braga é trazer à baila essa estranha dualidade do Ser e do instante fotográfico, eliminando as fronteiras entre o Eu e aquilo que the parece alheio: o mundo da alteridade radical; a partir da montagem de instantes sucessivos. $\mathrm{E}$, desse modo, fazer com que nos percamos num espaço sem fronteiras onde o tempo é também espaço, onde o vivo torna-se o morto e o morto torna-se o vivo. Em Sal e Prata, a ação de Braga de cavar um buraco com as próprias mãos e uma colher e enterrá-la, coloca em questão a própria natureza do instante fotográfico e do sujeito que se depara com ele. $O$ instante fotográfico apresenta-se no seu limiar, porque é ele mesmo, enquanto objeto, que está sendo questionado. Em Sal e Prata, fotografia e sujeito encontram a sombra de si mesmos.

\section{CONSIDERAÇÕES FINAIS}

Quisemos, aqui neste texto, provocar e ampliar os conceitos de imagem e de fotografia. Primeiramente, abordamos a imagem literária como fotografia, a partir do instante que se configurou no desenvolvimento de uma ação. Paralelamente, desenvolvemos a ideia da imagem do vórtice sugerida por Poe. Temos consciência que em muitos momentos chegamos ao limite daquilo que é aceito como uma imagem literária e daquilo que é aceito como uma imagem visual. Estar no limite era uma condição inicial. Contudo, nosso primeiro interesse foi sempre a recepção de uma imagem. Desse modo, não é tanto a imagem e suas funções descritivas que a tornam artisticamente potente, mas a maneira como ela é apresentada a nós. Ou seja, a imagem não se faz potente na representação de dada realidade, mas em sua apresentação. Vimos que, para isso, Poe lançou mão de um dado método. Muitas imagens representativas, porém incompletas, deram-Ihe a possibilidade de sugerir uma imagem muito mais abrangente de seu objeto - o vórtice - que se faz específica para cada um dos leitores-espectadores. A imagem do vórtice só pode ser construída, em sua potência e subjetividade total, no espectador. Apontamos que a imagem do vórtice carrega consigo um saber particular, o qual denominamos trágico, porque nos colocou em contato com uma realidade que não é usual e sim misteriosa e profunda, e ao mesmo tempo muito conhecida nossa: o medo de cair. 
Em nossa análise do método de Poe, a fotografia apresentou-se conceitualmente. Ela mostrou-nos dois instantes: um referenciando-se ao tempo contínuo e finito, cujo paralelo é o tempo real, da nossa percepção diária, e o outro o tempo infinito e descontínuo, concebido na particularidade da interpretação do espectador diante da imagem do vórtice. A imagem que nos é apresentada em Descida ao Maelström pode ser fotográfica, mas não é fotografável à maneira de Bresson.

No segundo capítulo, continuamos testando nossa concepção de imagem e de fotografia com $A$ incredulidade de São Tomé. Nosso limite nesse momento foi entre pintura e fotografia. Vimos que ambas mantém estreita relação. O método de Caravaggio é construir uma imagem a partir de planos de luz. Sob este ponto de vista, dissemos que o artista é um fotógrafo que se interessava por um instante último de uma agonia. Sua vontade era deter o fluxo contínuo do tempo, e, a partir disso, falar-nos de uma realidade mutável, onde beleza e horror, luz e treva, entrelaçam-se, e, desse modo, revelam o 'segredo do mundo'. Entendemos que o instante fotográfico, a aparência congelada do visível, é um véu mentiroso, o qual nos protege da realidade sombria do mundo. Essa aparência imobilizada conduziunos a um frenesi para 'dentro' da imagem, para dentro de nós mesmos. A vertigem foi suscitada em nós por uma dúvida, por uma incerteza quanto àquilo que percebíamos. A visibilidade tornou-se tangibilidade. A circularidade do espaço entrelaçou-se à circularidade temporal num vórtice solitário. O real mais uma vez não pode ser representado, pois ele se fez no cruzamento entre o objeto-imagem e a luz que emanou do nosso olhar.

Consideramos, aqui, que o pensamento fotográfico está atrelado a uma forma particular de conceber o mundo. Na cultura ocidental, o sentido da visão, sobrepondo-se aos demais, encontra na fotografia as bases para tal fundamento. Visão e verdade tornam-se sinônimos. Desse modo, construímos uma realidade fantasmagórica na qual o real é aquilo que pode ser descrito em termos visuais. $O$ conhecimento a partir do visível levado a seu extremo é também o mais dissimulado e o mais obscuro. E, de forma reversa, o conhecimento estabelecido a partir da interioridade silenciosa do corpo, com todos os sentidos unificados, é aquele que se pode revelar o mais iluminado. Contudo, a partir da aparência escandalosa do visível, pode-se chegar à mudez murmurante da interioridade corpórea, como faz a 
arte de Caravaggio. O Tomé que encontramos em Caravaggio difere do bíblico. Este toma o visível como caminho único à verdade, aquele faz do visível uma via para o tangível.

Ao poucos, no último tópico, fomos entendendo o espaço no qual estávamos adentrando. Vimos que o Eu lá, comportou-se de maneira diferente. Entendemos que nesse espaço, o contemporâneo, todas as medidas, todos os critérios são relativos. E aí se encontra nossa tragédia. Nosso tempo e nosso espaço são heteróclitos. A nossa vontade, que anteriormente (período moderno) tudo parecia endireitar e resolver; míngua, e enfraquece diante de um mundo Baudrillariano. Entendemos também que o Eu e o mundo de alguma maneira não mais se opunham. E, a partir disso, começamos a entender a relação claustrofóbica entre o Eu e o 'outro'. Colocando essa relação em nossos termos: entre o sujeito e a Fotografia. Esta apareceu como o 'outro' que está tão próximo de nós que dele quase nada sabemos, porque o excesso de proximidade oblitera-nos a visão.

As questões, que inicialmente giraram em torno da imagem e de como essa é recepcionada a partir da noção de instante fotográfico, desembocaram na especificidade da imagem fotográfica a partir do trabalho Sal e Prata de Rodrigo Braga. O instante fotográfico, pensado, até então, a partir da literatura e da pintura, foi trabalhado a partir da vídeo-performance. Aqui o instante fotográfico foi construído a partir da imagem-movimento (vídeo). As ideias de mobilidade e de imobilidade é que se intercambiaram. O movimento de uma ação gerou o estático (o instante), e o estático do instante, por sua vez, gerou o movimento dado pelo olhar do espectador. Encontramos o instante tanatócrito, ou como preferimos, o instante de uma ausência.

Queremos, nestas últimas linhas, salientar algumas questões referentes à Fotografia. A fotografia objetiva cega-nos verdadeiramente. Acreditar nessa fotografia como sendo a verdade do mundo é como sugere Flusser (1998): ser um indivíduo programado por uma conduta social. Em contrapartida, a fotografia artística salva-nos desse terrível destino. Liberta-nos da magia negra e aponta à outra: a magia branca. 


\section{ANEXOS}

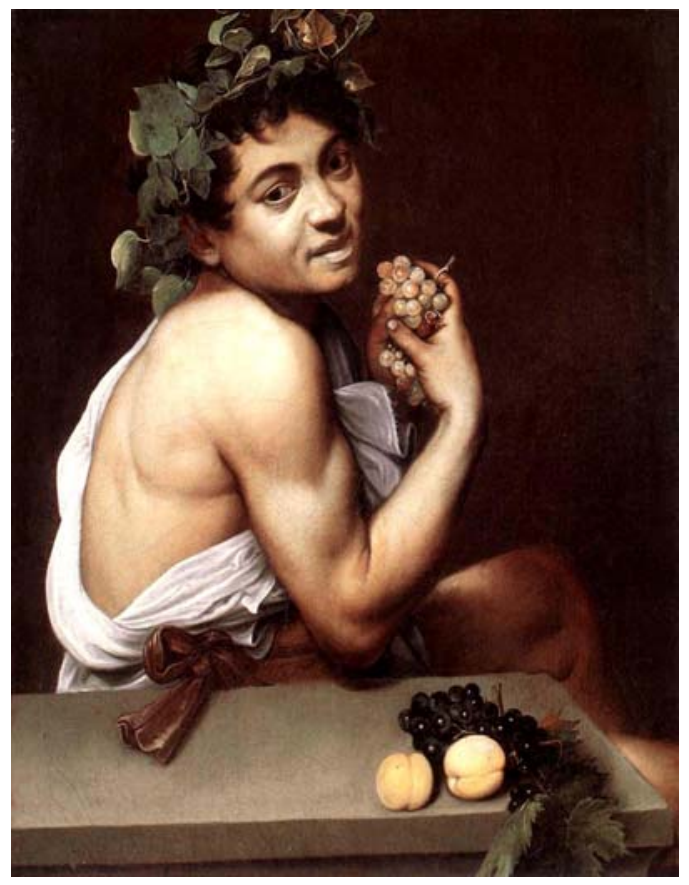

FIGURA 3 - Michelangelo Merisi da Caravaggio, Pequeno Baco doente, 1593-94, óleo s/ tela 67 x 53 $\mathrm{cm}$, galeria Borghese, Roma.

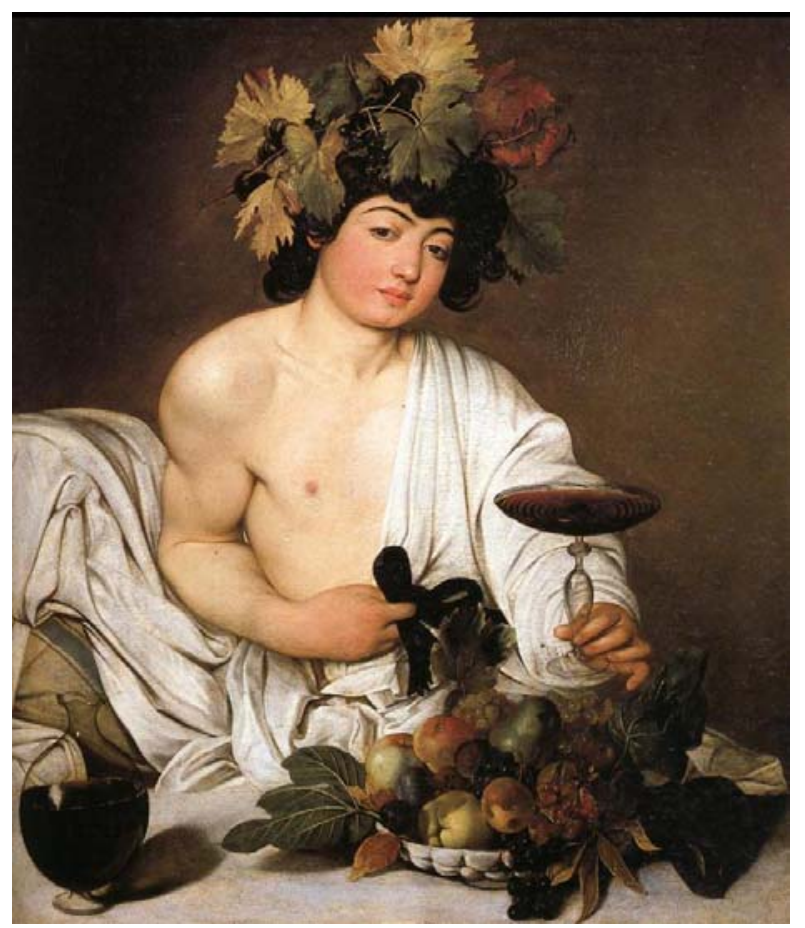

FIGURA 4 - Michelangelo Merisi da Caravaggio, Baco, 1596-97, óleo s/ tela, 95 ×85 cm, Daleriadegliuffizi, Florença. 


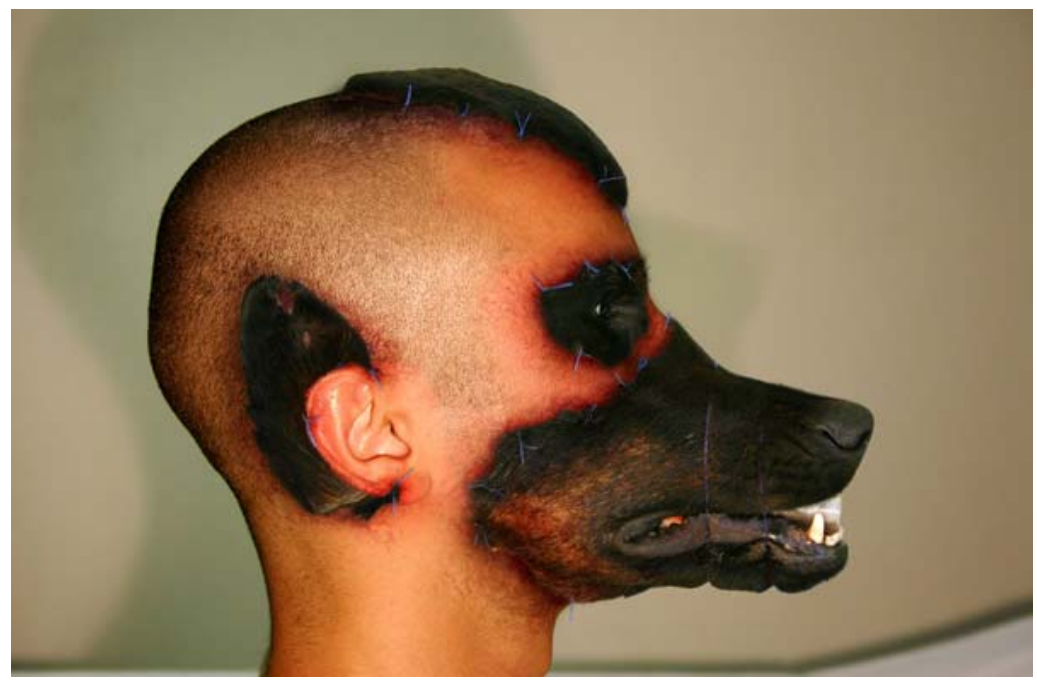

FIGURA 5 - Rodrigo Braga, Fantasia de Compensação, 2004, fotografia.

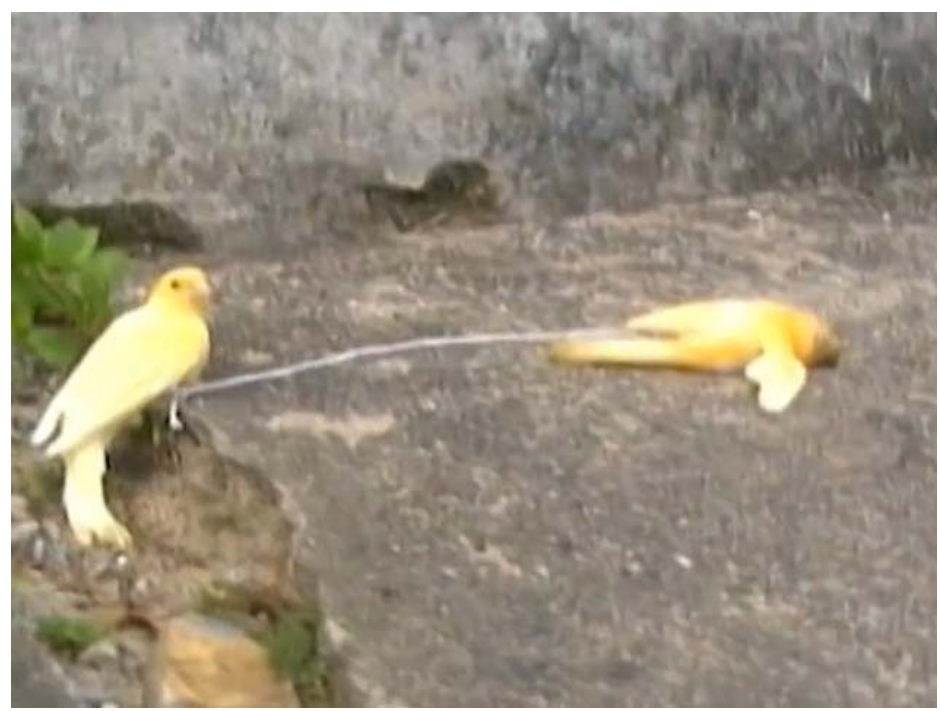

FIGURA 6 - Rodrigo Braga, Vontade I, 2007, vídeo. 


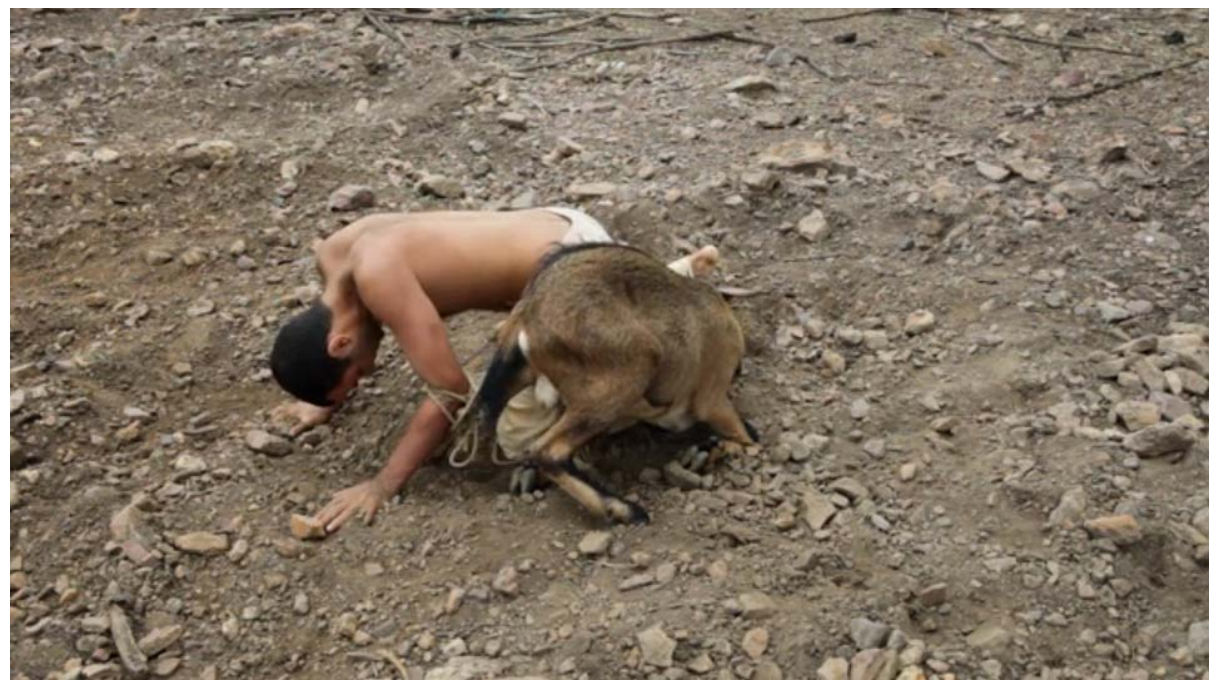

FIGURA 7 - Rodrigo Braga, Tonus III, 2012, vídeo-performance.

\section{Referências Bibliográficas}

BACHELARD, Gaston. O Ar e os sonhos: Ensaio sobre a imaginação do movimento. 2. ed. São Paulo: Martins Fontes, 2001.

BARTHES, Roland. A Câmara Clara: nota sobre a fotografia. Lisboa: Edições 70, 2008.

BAUDRILLARD, Jean. A Troca impossível. Rio de Janeiro: Nova Fronteira, 2002.

1923-97. 1. Reimp. 2004, São Paulo: Cosac Naify, 2000.

BRAGA Rodrigo. Sal e prata. vimeo.com3427445, 2010.

BRAGANÇA DE MIRANDA A., José. Queda sem fim. Lisboa: Nova Vega, Limitada, 2006.

DUBOIS, Philippe. O ato fotográfico e outros ensaios. Coleção ofício de arte e forma, Campinas, SP: Papirus, 1994.

FORBES, Jorge. In: http://www.jorgeforbes.com.br/br/avesso-doavesso/extimidade.html. Acesso em 30/05/2013.

FLORES GONZÁLEZ, Laura. Fotografia e pintura: dois meios diferentes? Coleção Arte \& Fotografia, São Paulo: Editora WMF Martins Fontes, 2011.

FLUSSER, Vilém. Ensaiosobre a fotografia: paraumafilosofia da técnica. Coleção 
Mediações, Lisboa: RelógioD’ÁguaEditores, 1998

A História do diabo. Coleção comunicações, 3. ed. São Paulo: Annablume, 2008.

FREUD, Sigmund. Mais além do princípio do prazer. In: Obras completas de Sigmund Freud, v. VIII, Rio de Janeiro: Editora Delta S.A.

LONGHI, Roberto. Caravaggio / Roberto Longhi. São Paulo: Cosac Naify, 2012.

MACHADO, Arlindo. A ilusão especular: introdução à fotografia. São Paulo: Brasiliense, 1984.

MICHAELIS. Moderno dicionário da língua portuguesa. São Paulo: Companhia Melhoramentos, 1998.

NIETZSCHE W., Friedrich. A origem da tragédia. 12. ed. São Paulo, 2004.

PAGLIA, Camille. Personas Sexuais: Arte e decadência de Nefertite a Emily Dickson. 1. ed. 4. reimp., São Paulo: Companhia das Letras, 1994.

POE A., Edgar. Descida ao Maelström. In: Queda sem fim, Lisboa: Nova Vega, Limitada, 2006.

SOULAGES, François. Estética da fotografia: Perda e permanência. São Paulo: Editora Senac São Paulo, 2010. 